\title{
THE POTENTIAL OF ENTOMOPATHOGENIC NEMATODES AS BIOCONTROL AGENTS FOR CLOVER ROOT WEEVIL (SITONA LEPIDUS)
}

\author{
N.L. BELL ${ }^{1}$, T.A. JACKSON ${ }^{2}$ and T.L. NELSON ${ }^{2}$ \\ ${ }^{I}$ AgResearch, Ruakura Research Centre, Private Bag 3123, Hamilton, \\ New Zealand \\ ${ }^{2}$ AgResearch, Canterbury Agriculture and Science Centre, \\ PO Box 60, Lincoln, New Zealand
}

\begin{abstract}
The efficacy of the entomopathogenic nematodes Heterorhabditis zealandica, $H$. bacteriophora, Steinernema carpocapsae and $S$. feltiae against clover root weevil (CRW) larvae and pupae was determined in petri dish and pot experiments. Field collected third instar (L3)-pupal CRW immature stages were used, and experiments were conducted in a controlled environment room at $18^{\circ} \mathrm{C}$. Weevil survival and development was assessed 7 and 10 days after nematode inoculation for petri and pot experiments respectively. All nematodes significantly reduced CRW survival, and all except $S$. feltiae prevented adult development. Under the conditions used in this study, Heterorhabditis spp. were generally more effective than Steinernema spp. Results are discussed in terms of the potential use of entomopathogenic nematodes as biocontrol agents for this clover pest.

Keywords: clover root weevil, Heterorhabditis zealandica, $H$. bacteriophora, Steinernema carpocapsae, S. feltiae.
\end{abstract}

\section{INTRODUCTION}

The clover root weevil (Sitona lepidus Gyllenhal - CRW) was first recognised in New Zealand in 1996 (Barratt et al. 1996) and has the potential to be a serious pest of white clover (Trifolium repens) in pastures (Willoughby et al. 1997; Murray and Willoughby 1998). Adult CRW feed on foliage, but more seriously, larvae feed on roots. Management options for CRW currently being explored include agrochemicals, attractants, pasture management, plant selection and biocontrol with microbial pathogens and parasitoids (Willoughby et al. 1999).

The successful use of entomopathogenic nematodes as biocontrol agents for root feeding weevils has been demonstrated in New Zealand for control of garden weevil (Phlyctinus callosus) in asparagus (Prestidge and Willoughby 1990); black vine weevil (Otiorhynchus sulcatus) in strawberries (Jackson et al. 1985) and nursery plants (Ferguson et al. 1990); and white fringed weevil (Naupactus leucoloma) in the laboratory (Jackson et al. 1981).

The entomopathogenic nematodes Steinernema feltiae Filipjev, S. bibionis Bovien and Heterorhabditis bacteriophora Poinar have been found to be effective against Sitona spp. weevils (including CRW) in laboratory experiments in Poland (Wiech and Jaworska 1990). Since concerns about non-target effects coupled with rigorous biosecurity regulations mean that it may now take 5-7 years before being able to release imported biocontrol agents, this study investigated the efficacy of locally occurring entomopathogenic nematodes which could be adopted more rapidly. 


\section{METHODS}

\section{Petri dish experiment}

Motumaho shallow silty peat from beneath pasture at the Ruakura Agricultural Research Centre was sieved, moistened and placed into 25 petri dishes to a depth of ca $5 \mathrm{~mm}$. CRW larvae were collected from soil beneath pasture on 18 February 2000 from the same site as the soil. Five field collected L3-pupal CRW were placed into each dish and covered with a further ca $5 \mathrm{~mm}$ layer of moistened soil. Head capsules of 34 further larvae collected at the same time as those above were measured after killing in $70 \%$ ethanol using a stereomicroscope at $63 \times$ magnification. Larvae were assigned to stages as described by Müller (1963) and this allowed subsequent determinations to be estimated visually without the need for microscopic examination.

Heterorhabditis zealandica Poinar, H. bacteriophora, Steinernema carpocapsae Weiser and S. feltiae entomopathogenic nematodes were extracted from Greater wax moth (Galleria mellonella) larvae by the method of White (1927). Nematodes were used for inoculum within seven days of beginning extractions. Nematodes were counted using a Doncaster dish (Doncaster 1962) and diluted to obtain the desired numbers for inoculum. Each nematode species was inoculated onto each of five dishes in a suspension with tap water, with five dishes receiving only tap water. One $\mathrm{ml}$ of nematode suspension was applied onto the surface of the soil layer covering CRW larvae, immediately after CRW larvae were placed into dishes. The soil surface was then watered with tap water to wash the nematodes into the soil. Dishes were sealed with Parafilm ${ }^{\circledR}$ and placed in a controlled environment room at $18^{\circ} \mathrm{C}$ inside liver pails (170 $\mathrm{mm}$ square $\times 190 \mathrm{~mm}$ tall) covered with black polythene, in a randomised block design.

CRW survival and development was assessed by hand sorting soil seven days after inoculation with nematodes. The data were analysed using the generalised linear regression model of Genstat 5 (Release 4.2) after logit transformation.

\section{Pot experiment}

Motumaho shallow silty peat (as above) was sieved and placed into twenty five $350 \mathrm{ml}$ pots $(80 \mathrm{~mm}$ maximum diameter $\times 90 \mathrm{~mm}$ tall). Field collected white clover (Trifolium repens) rooted stolon cuttings were planted into soil filled pots on 27 January 2000. Pots were placed in a $5 \times 5$ Latin square design in a controlled environment room at $18^{\circ} \mathrm{C}$ and $16: 8 \mathrm{~h}$ light:dark, and watered regularly. Ten field-collected L3-L5 CRW larvae were introduced into each pot seven days after planting.

Heterorhabditis zealandica, Steinernema carpocapsae and $S$. feltiae were extracted and counted from wax moth larvae as above. Each nematode species was inoculated into each of five pots, seven (S carpocapsae) or eleven ( $H$. zealandica and S. feltiae) days after introduction of CRW larvae, with five untreated control pots maintained for each inoculation day. For each pot, $1 \mathrm{ml}$ of nematode suspension was inoculated into each of four ca $30 \mathrm{~mm}$ deep $\times 5 \mathrm{~mm}$ diameter holes made in the soil surface after which the holes were re-filled with soil and immediately watered.

CRW survival was assessed ten days after nematode inoculation by hand sorting soil from each pot, and developmental stages of live and dead weevils were estimated. Data comparisons were made by an exact $2 \times 2$ binomial test (Yates 1984).

\section{Petri dish experiment}

\section{RESULTS}

There was significantly $(\mathrm{P}<0.05)$ greater survival of CRW larvae in the untreated dishes than those treated with any of the nematodes (Table 1). None of the dead CRW larvae recovered from untreated dishes contained entomopathogenic nematodes whereas all dead larvae from treated dishes did (data not shown). A significantly $(\mathrm{P}<0.05)$ greater proportion of CRW survived treatment with $S$. carpocapsae than survived treatment with either of the Heterorhabditis species (Table 1). 
TABLE 1: Survival of CRW larvae untreated or treated with entomopathogenic nematodes in petri dishes. Figures in parentheses are SEM.

\begin{tabular}{lcc}
\hline Treatment & Nematodes/dish & CRW survival (\%) \\
\hline Untreated & 0 & 85 \\
S. carpocapsae & 161 & $57(10)$ \\
S. feltiae & 153 & $42(10)$ \\
H. bacteriophora & 156 & $22(9)$ \\
H. zealandica & 169 & $23 \quad(9)$ \\
\hline
\end{tabular}

From the initial introductions, CRW pupae developed into adult weevils only in untreated and $S$. feltiae treated dishes $(\mathrm{P}<0.10)$ (Table 2). A similar result was observed for L3 larvae, which all moulted to L4 in untreated dishes but did not in nematode treated dishes ( $\mathrm{P}<0.10$ for $S$. carpocapsae, $S$. feltiae and $H$. bacteriophora). There was no significant effect of nematode treatment on other life stages of the weevil (Table 2).

TABLE 2 Percentage of CRW developmental stages before (initial) and after treatment or non-treatment with entomopathogenic nematodes in petri dishes. Data include alive and dead weevils. Figures in parentheses are SEM.

\begin{tabular}{|c|c|c|c|c|c|}
\hline Treatment & Adults & Pupae & L5 & L4 & L3 \\
\hline Initial & 0 & 12 & 36 & 36 & 16 \\
\hline Untreated & $15 \quad(8)$ & 26 (9) & $30 \quad(10)$ & 30 (10) & $0 \quad(0)$ \\
\hline S. carpocapsae & $0 \quad(0)$ & 21 & $49 \quad(10)$ & $18 \quad(8)$ & $13(7)$ \\
\hline S. feltiae & $5 \quad(4)$ & $17 \quad(8)$ & $40 \quad(10)$ & 25 & $13(7)$ \\
\hline H. bacteriophora & $0 \quad(0)$ & $22 \quad(8)$ & $39 \quad(10)$ & $26 \quad(9)$ & $13(7)$ \\
\hline H. zealandica & $0 \quad(0)$ & $22 \quad(8)$ & $42 \quad(10)$ & 27 (9) & $9(6)$ \\
\hline
\end{tabular}

\section{Pot experiment}

In the pot experiment there was significantly $(\mathrm{P}<0.001)$ greater survival of $\mathrm{CRW}$ larvae in untreated pots than in those treated with any of the nematodes (Table 3). As with the dish experiment none of the dead CRW larvae recovered from untreated pots contained entomopathogenic nematodes. Of the treated pots one dead larvae not infected with nematodes was found only in the $S$. feltiae treatment (data not shown).

TABLE 3: Survival of CRW larvae treated or untreated with entomopathogenic nematodes in pots. Figures in parentheses are SEM.

\begin{tabular}{lrrr}
\hline Treatment & Nematodes /pot & \multicolumn{2}{c}{ CRW survival (\%) } \\
\hline Untreated & 0 & 97 & $(3)$ \\
S. carpocapsae & 48,880 & 4 & $(4)$ \\
Untreated & 0 & 100 & $(0)$ \\
S. feltiae & 30,200 & 39 & $(14)$ \\
H. zealandica & 40,680 & 0 & $(0)$ \\
\hline
\end{tabular}

As in the dish experiment, CRW introduced in the L5 stage only developed into adults in the untreated and $S$. feltiae treated pots $(\mathrm{P}<0.01$ for untreated versus H. zealandica comparison) (Table 4$)$. There was a significantly $(\mathrm{P}<0.05)$ greater proportion of L5 CRW larvae in pots treated with $\mathrm{H}$. zealandica compared to untreated and S. feltiae treated pots (Table 4). 
TABLE 4: Percentage of CRW developmental stages before (initial) and after treatment or non-treatment with entomopathogenic nematodes in pots. Data include alive and dead (nematode infected and nematode free) weevils. Figures in parentheses are SEM.

\begin{tabular}{|c|c|c|c|c|c|c|}
\hline Treatment & Adults & Pupae & & 5 & L4 & L3 \\
\hline Initial & 0 & 0 & 53 & & 41 & 6 \\
\hline Untreated & $6 \quad(4)$ & $42 \quad(8)$ & 25 & (7) & (5) & $19(7)$ \\
\hline S. carpocapsae & $0 \quad(0)$ & 39 (10) & 44 & (10) & 17 & $0 \quad(0)$ \\
\hline Untreated & $31 \quad(8)$ & $37 \quad(8)$ & 3 & (3) & 20 & $9 \quad(5)$ \\
\hline S. feltiae & $8 \quad(7)$ & $54(14)$ & 8 & (7) & $15(10)$ & $15(10)$ \\
\hline H. zealandica & $0 \quad(0)$ & 31 (9) & 46 & (10) & 23 & $0 \quad(0)$ \\
\hline
\end{tabular}

\section{DISCUSSION}

Under the conditions used in this study, it appears that all species of entomopathogenic nematodes were able to kill CRW within 7-10 days of application. Heterorhabditis spp. nematodes had a greater effect on CRW larvae than Steinernema spp. in the petri dish experiment and $H$. bacteriophora was more effective than $S$. feltiae in the pot experiment. In these trials, after treatment with $S$. carpocapsae, $H$. bacteriophora and $H$. zealandica none of the larvae or pupae present moulted to adults. In the pot experiment, larval development was not halted to the same extent as the petri dish experiment, probably due to the larger volume of soil and therefore greater searching behaviour needed for nematodes to encounter CRW larvae. Again, $S$. feltiae had less effect and some CRW emerged as adults following this treatment. Overall, it would appear that, under the conditions used in this study, the Heterorhabditis sp. nematodes are the most likely to be effective biocontrol agents for CRW.

For any biocontrol agent to be effective in the field it must be able to operate under realistic climatic conditions. Both the petri dish and pot experiments in this study were maintained at $18^{\circ} \mathrm{C}$, which is similar to the 20 year (1977-1997) average monthly 10 $\mathrm{cm}$ earth temperatures experienced in the Waikato for December, January and February (e.g. $17.3,18.6$ and $18.5^{\circ} \mathrm{C}$ respectively at Ruakura Research Centre) (National Climate Centre, National Institute of Water and Atmospheric Research Ltd.). Large larval populations of CRW have been observed during these months (Gerard et al. 1999) indicating that the entomopathogenic nematodes studied here, which operate at realistic temperatures, may be effective in a field situation.

CRW larval abundance is not, however, determined solely by temperature but more importantly in summer by rainfall (Gerard et al. 1999; Willoughby and Hardwick 1999). It appears that rainfall from December to January may be important in determining whether a summer generation of CRW occurs (Gerard et al. 1999). Apart from this rainfall-dependant summer generation, CRW larval abundance peaks in August-September (Willoughby et al. 1997). The 20 year average $10 \mathrm{~cm}$ soil temperature during these months in Hamilton is 8.5 and $10.4^{\circ} \mathrm{C}$ respectively (National Climate Centre), so it may be that cool active entomopathogens would be effective.

Cold tolerant strains of Steinernema spp. (Finney-Crawley 1985; Wright and Jackson 1992; Mracek et al. 1997) and Heterorhabditis spp. (Griffin and Downes 1994) have been isolated overseas and in New Zealand it appears that $H$. zealandica may be a good candidate for selecting a cold tolerant strain (Wharton and Surrey 1994). A further advantage of field application of entomopathogenic nematodes during August-September is that conditions at this time of year may negate two of the limitations to establishment success of applied nematodes, namely low relative humidity (MacVean et al. 1982) and high UV radiation (Gaugler and Boush 1978). Experiments to determine the thermal activity range of the nematodes studied here are currently being carried out.

\section{ACKNOWLEDGEMENTS}

The authors thank Ms Lee Davis and Ms Michelle Miles for technical assistance and Dr Neil Cox for statistical analyses. 


\section{REFERENCES}

Barratt, B.I.P., Barker, G.M. and Addison, P.J., 1996. Sitona lepidus Gyllenhal (Coleoptera: Curculionidae), a potential clover pest new to New Zealand. N.Z. Entomol. 19: 23-30.

Doncaster, C.C., 1962. A counting dish for nematodes. Nematologica 7: 334-336.

Ferguson, C.M., Barratt, B.I.P., Jones, P.A. and Garnham, M.L., 1990. Control of black vine weevil (Otiorhynchus sulcatus) larvae with different rates of a parasitic

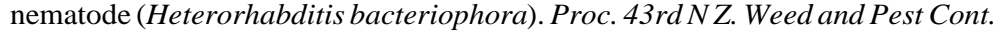
Conf: : 67-69.

Finney-Crawley, J.R., 1985. Isolation of cold tolerant Steinernematid nematodes in Canada. J. Nematol. 17: 496 (Abstract).

Gaugler, R. and Boush, G.M., 1978. Effects of ultraviolet radiation and sunlight on the entomogenous nematode, Neoaplectana carpocapsae. J. Invert. Path. 32: 291296.

Gerard, P.J., Addison, P.J., Hardwick, S. and Willoughby, B.E., 1999. Establishment of the invader: Insights into life history and biology of Sitona lepidus in the Waikato region of New Zealand. Proc. 7th Australasian Conf. Grassland Invert. Ecol: : 43-51.

Griffin, C.T. and Downes, M.J., 1994. Recognition of low-temperature infective isolates of the entomopathogenic nematode Heterorhabditis spp. (Rhabditida: Heterorhabditidae). Nematologica 40: 106-115.

Jackson, T.A., Bedding, R.A., Trought, T.E.T., Kain, W.M. and East, R., 1981. The potential use of nematodes for the control of pasture pests. Proc. 34th N. Z. Weed and Pest Cont. Conf:: 170-172.

Jackson, T.A., Pearson, J.F. and Barrow, T.H., 1985. Control of the black vine weevil in strawberries with the nematode Steinernema glaseri. Proc. 38 th N.Z. Weed and Pest Cont. Conf: : 158-161.

MacVean, C.M., Brewer, J.W. and Capinera, J.L., 1982. Field tests of antidesiccants to extend the infection period of an entomogenous nematode, against the Colorado potato beetle. J. Econ. Ento. 75: 97-101.

Mracek, Z., Becvar, S., Rezac, P., Kindlmann, P. and Webster, J.M., 1997. Canadian steinernematid (Nematoda) isolates and their infectivity, under cold conditions, to greater wax moth (Galleria mellonella) larvae. Biol. Cont. 8: 160-164.

Müller, H., 1963. Zur Populationsdynamik von Sitona Germar (Cuculionidae) auf Luzerne und Rotklee unter besonderer Berücksichtigung entomophager Parasiten. Zool. Jb. Syst. Bd. 90: 659-696.

Murray, P.J. and Willoughby, B., 1998. Feeding preferences of Sitona lepidus (clover root weevil) on Trifolium spp. in New Zealand. Tests Agrochem. and Cult. 19: 5859.

Prestidge, R.A. and Willoughby, B., 1990. Control of garden weevil (Phlyctinus callosus) larvae and pupae with a parasitic nematode and a fungal pathogen.Proc. 43rd N.Z. Weed and Pest Cont. Conf.: 63-66.

Wharton, D.A. and Surrey, M.R., 1994. Cold tolerance mechanisms of the infective larvae of the insect parasitic nematode, Heterorhabditis zealandica Poinar. Cryo letters 15: 353-360.

White, G.F., 1927. A method for obtaining infective nematode larvae from cultures. Sci. 66: 302-303.

Wiech, K. and Jaworska, M., 1990. Susceptibility of Sitona weevils (Col., Curculionidae) to entomogenous nematodes. J. Appl. Ento. 110: 214-216.

Willoughby, B., Addison, P. and Baker, M., 1997. Clover root weevil (Sitona lepidus) - a threat to the sustainability of white clover in New Zealand pastures? Proc. N.Z. Grassland Assoc. 59: 23-27.

Willoughby, B., Goldson, S., Addison, P., Hardwick, S., Gerard, P. and Eerens, H., 1999. Clover root weevil (Sitona lepidus) - The New Zealand response to a major biosecurity breach. Proc. 7th Austral. Conf. Grassland Invert. Ecol.: $35-42$. 
Willoughby, B. and Hardwick, S., 1999. The effect of summer irrigation on population dynamics and reproductive status of adult Sitona lepidus in the Waikato. Proc. N.Z. Plant Prot. Conf. 52: 245-249.

Wright, P.J. and Jackson, T.A., 1992. Efficacy of entomogenous nematodes for control of porina (Wiseana cervinata) in Canterbury pastures during winter. N.Z. J. Agric.Res. 35: 435-439.

Yates, F., 1984. Tests of significance for $2 \times 2$ contingency tables. J. Royal Stat. Soc. 147: 426-463. 